Int. Archs Allergy appl. Immun.1981;64:I-VI

\title{
Contents, Vol. 64, 1981
}

\section{No.l}

Original Paper

Strain Differences in the Proliferative Response of Murine Spleen Cells to Mitogen

Malavé, 1 1

Immunological Studies on Modified Enzymes. I Soluble L-Asparaginase/Mouse Albumin Copolymer with Enzyme Activity and Substantial Loss of Immunogenicity

Yagura, T.; Kamisaki, Y.; Wada, H.; Yamamura, Y 11

Serological and Immunohistological Studies on Lepromatous Leprosy

Kano, K.; Aranzazu, N.; Nishimaki, T.; Convit, J.; Albini, B.; Milgrom, F 19

Mediators of Immune-Complex-Induced Aggregation of Polymorphonuclear Neutrophis.

II. Platelet-Activating Factor as the Effector Substance of Immune-Induced Aggregation

Camussi, G.; Tetta, C; Bussolino, F.; Caligaris Cappio, F.; Coda, R.; Masera, C; Segoloni, G. . 25 Investigation of a Syngeneic Murine Model for the Study of IgE Antibody Regulation with Isologous Antiidiotypic Antibodies

Blaser, K.; Nakagawa, T.; Week, A. L. de 42

Neutrophil-Derived Eosinophil Chemotactic Factor Production Induced by Immune Complexes Czarnetzki, B. M.; Schulz, W 51

Identification and Functional Characterization of Monocytes in Rheumatoid Synovial Fluid

Thorsteinsson, L.; Abrahamsen, T. G; Frøland, S. S.; Kåss, O. E 60

Joint Inflammation in Rabbits Induced by Preformed Immune Complexes

Bjursten, L. M.; Bagge, U.; Ahlstedt, S 67

Enhanced Chemiluminescence Response of Phagocyting Monocytes from Sarcoidosis Patients

Kanegasaki, S.; Homma, J.Y.; Hamma, H.; Washizaki, M 72

Immunoelectrophoretic Pattern of Klebsieila $\mathrm{O}$ and $\mathrm{K}$ Antigens

Kaijser, B.; Nimmich, W 80

Suppression of Reaginic Antibodies with Modified Allergens. III. Preparation of Tolerogenic Conjugates of Common Allergens with Monomethoxypolyethylene Glycols of Different Molecular Weights by the Mixed Anhydride Method

Wie, S.I.; Wie, C.W.; Lee, W.Y.; Filion, L.G.; Sehon, A.H.; Åkerblom, E 84

Suppression of Reaginic Antibodies with Modified Allergens. IV. Induction of Suppressor T Cells by Conjugates of Polyethylene Glycol (PEG) and Monomethoxy PEG with Ovalbumin Lee, W.Y.; Sehon, A.H.; Åkerblom, E 100

Immunogenetics of the Dl Serum Antigen of Rhesus Monkey (Macaca mulatta)

Capparelli, R.; Iannelli, D 115

Book Reviews 118

Announcement $\quad 120$

No. 2

Original Paper

Flow Cytometric Analysis of Normal and Neoplastic Human Hematopoietic Surface Antigens 
Attallah, A.M.; Strong, D.M.; Slease, R.B.; Noguchi, P.D 121

Influence of a Bovine Spleen Extract on Immunological Responses in Mice

Millerioux, L.; Lenfant, M.; Oleson, D.; Mayadoux, E 128

IV

Contents

Hypergammaglobulinaemia E in Hodgkin's Disease and Its Relationship to Atopy or a Familial Predisposition to Atopy

Amlot, P.L.; Slaney, J 138

Fractionation and Characterization of Allergens Extracted from Eggs of Schistosoma japonicum

Owhashi, M.; Ishii, A 146

Measurement of'Blocking Antibodies' to Pollen Antigens by Radiolabelled Protein A from

Staphylococcus aureus

Puttonen, E.; Maasch, H.J 157

A New Technique for Determination of Immobilizing Antibodies against E. coli Using Capillary Tubes

Kaijser, B 167

Cellular Cooperation in Polymorphonuclear Leukocyte Chemotaxis: Augmentation by

Neutrophil Cytoplasm

Takeuchi, A.; Persellin R.H 171

Generation of a Phagocytosis-Stimulating Factor by Polymorphonuclear Neutrophils during

Phagocytosis

Ishibashi, Y.; Yamashita, T 181

Immune Complexes and Cryoproteins in Ascitic Fluid of Patients with Alcoholic Liver Disease Quismorio, F.P., Jr.; Kaufman, R.L.; Halle, P.; Hoefs, J.C 190

Evaluation of Circulating Immune Complex-Like Material for Development of Skin Reactions in Connection with Penicillin Therapy

Ahlstedt, S.; Bjursten, L.M.; Hanson, L.Å.; Lidin-Janson, G.; Mobacken, H.; Belin, L 195

Flow-Cytometric Analysis of Human Basophil Degranulation. III. Degranulation Induced by

Allergens and Antibodies in Hay Fever and Bee Venom Allergic Patients

Nakagawa, T.; Moyseyenko, O.; Week, A.L. de 201

Induction of Immunological Tolerance to the Penicilloyl Antigenic Determinant. III. Suppression of Benzylpenicilloyl-Specific IgE Antibody Formation by Cleavable Penicilloylated Dextran

Nakagawa, T.; Otz, U.; Week, A.L. de; Schneider, C.H 210

Decrease in Cholera Toxin-Binding T Cells in Aged Mice and Human Volunteers

Tsuru, S.; Zinnaka, Y.; Nomoto, K 217

Measurement of Human Serum IgE and IgA by Reverse Passive Antiglobulin

Haemagglutination

Scott, M.L.; Thornley, M.J.; Coombs, R.R.A.; Bradwell, A.R 222

Comparison of Red-Cell Linked Anti-IgE and 125I-Labelled Anti-IgE in a Solid-Phase System

for the Measurement of IgE Specific for Castor Bean Allergen

Scott, M.L.; Thornley, M.J.; Coombs, R.R.A 230

Short Communication

A Reappraisal of the Anti-Inflammatory Activity of Copper

West, G.B 236

Book Reviews 240

No. 3 
Original Paper

Antigen-Induced Histamine Release from Guinea Pig Basophils

Lett-Brown, M.A.; Thueson, D.O.; Grant, J.A 241

Antigen-Induced Brochial Anaphylaxis in Actively Sensitized Guinea Pigs. The Effect of

Booster Injection and Cyclophosphamide Treatment

Andersson, P 249

Contents

$\mathrm{V}$

Effects of N-(2-Mercaptopropionyl) Glycine on Neutrophil Locomotion

Patrone, F.; Dallegri, F.; Lanzi, G.; Sacchetti, C 259

A Method for Eliciting Indurated DTH Reactions to Soluble Protein Antigens in the Flank

Skin of Mice: Correlation of Visual Measurements with 12SI-UdR Uptake Indices

Brummer, E.; Bhardwaj, N.; Sherwood Lawrence, H 266

Isolation of a Low Molecular Weight Constituent from Kentucky Blue Grass Pollen Possessing

Carrier Activity of High Molecular Weight Constituent(s)

Ekramoddoullah, A.K.M.; Kisil, F.T.; Sehon, A.H 277

Early Rheumatoid-Like Joint Lesions in Rabbits Drinking Cows’ Milk

Coombs, R.R.A.; Oldham, G 287

Investigation of the Possible Involvement of IgE Anti-Salicyloyl Antibodies in Patients

with Urticaria

Krilis, S.; Gregson, R.P.; Basten, A.; Baldo, B.A 293

Allergy to Laboratory Animals: A Survey by Questionnaire

Davies, G.E.; McArdle, L.A 302

Adherent Suppressor Cells in Atopic Disease

Strannegård, I.-L 308

Epstein-Barr Virus Antibodies in Children with Atopic Disease

Strannegård, I.-L.; Strannegård, Ö 314

Nature oftheThymus Dependency of Mucosal Mast Cells. III. Mucosal Mast Cells in Nude Mice and Nude Rats, in B Rats and in a Child with the Di George Syndrome

Mayrhofer, G.; Bazin, H 320

Chronic Pruritic Dermatitis in Asthmatic Monkeys: A Subhuman Primate Analogue of Atopic

Dermatitis?

Patterson, R.; Harris, K 332

Influence of Bestatin, a New Immunomodulator, on Ig Secretion by Human Lymphocytes in

vitro and in vivo

Blomgren, H.; Forsgren, M.; Norberg, R.; Stedingk, L.-V.; Wasserman, J 338

Regulation of Allergic Reaction by Aerobic Corynebacterium equi Extract, CEF. I. Antigen-

Nonspecific Suppression of Reaginic Response in Mice

Furuichi, K.; Ezoe, H.; Katoh, H.; Adachi, H.; Obara, T 345

Short Communications

Interferon Immunoregulation of Antibody Response in Normal and Autoimmune Mice Is

Mediated

by Suppressor T Cell Subsets

Attallah, A.M.; Urritía-Shaw, A.; Khalil, R.Y.; Steinberg, A.D.; Ahmed, A 353

Book Reviews 359

No. 4 
Original Paper

Suppressor Cell Function in Respiratory Allergy. Modulation by Aminophylline and Isoproterenol

Rola-Pleszczynski, M.; Blanchard, R 361

Mast Cell Degranulation Associated with Sequestration and Removal of Trichinella spiralis Antigens

Justus, D.E.; Marakote, N 371

Antigen Concentration in Tissues of Rabbits with Systemic Chronic Serum Sickness

Neuland, C; Albini, B.; Brentjens, J.; Grossberg, A.I.; Andres, G.A 385

VI

Contents

Cytotoxicity of Cultured Mouse Spleen Cells against Natural Killer-Sensitive Target Cells.

Characterization of the Effector Cells

Oshimi, K.; Kano, S.; Sumiya, M.; Gonda, N.; Takaku, F 395

Nonspecific Esterase in Human Lymphocytes

Müller, J.; Keller, H. U.; Dürig, P.; Hagmann, J.; Cornioley, D.M.; Reinhard, J.; Ruchti, C;

Hess, M.W.; Cottier, $\mathrm{H} \quad 410$

Occupational Asthma Due to Inhalation of Chloramine-T. I. Clinical Observations and

Inhalation-Provocation Studies

Dijkman, J.H.; Vooren, P.H.; Kramps, J.A 422

Occupational Asthma Due to Inhalation of Chloramine-T. II. Demonstration of Specific IgE Antibodies

Kramps, J.A.; Toorenenbergen, A.W. van; Vooren, P.H.; Dijkman, J.H 428

Comparative Studies on Tree-Pollen Allergens, I. Isolation and Partial Characterization of a

Major Allergen from Birch Pollen (Betula verrucosa)

Apold, J.; Florvaag, E.; Elsayed, S 439

Detection of HLA-DRw Specificities by Mixed Agglutination

Kaweski, S.; Kano, K.; Milgrom, F 448

Immunologic Histamine Release in vitro from the Heart and Lung of the Cynomolgus Monkey

Weichman, B.M.; Hostelley, L.S.; Bostick, S.P.; Levi, R.; Chakrin, L.W 456

Studies on Histamine and Histaminase in Spring Catarrh (Vernal Conjunctivitis)

Mukhopadhyay, K.; Pradhan, S.C.; Mathur, J.S.; Gambhir, S.S 464

Short Communication

Inhibition by Sugars of Opsonization of Staphylococcus aureus in Fetal Calf Serum

Umeda, T; Niijima, T.; Egawa, K 469

Author Index 473 